\title{
ANTI-INFLAMMATORY THERAPY IN THE PREVENTION OF PERIODONTAL DISEASES TISSUE. MYTHS OR THEIR EFFICIENCY
}

\author{
Kolesnyk T. V., docent, c. med. s. \\ The first higher education institution "Kiev Medical University" \\ Department of therapeutic dentistry, \\ Kiev, Ukraine
}

DOI: https://doi.org/ 10.31435/rsglobal_ws/30092018/6136

\section{ARTICLE INFO}

Received: 12 July 2018

Accepted: 20 September 2018

Published: 30 September 2018

\section{KEYWORDS}

experiment,

the rat periodontal tissue diseases, integrated prevention.

\begin{abstract}
We have considered and proved that phospholipase model periodontitis considerably aggravates bone resorption of the alveolar process and flow in rats. Also in modeling disease decreased antioxidant defenses. At the same time as the application of complex preventive effectively prevent violations in the pulp, gums, alveolar process, prevented bone resorption of the alveolar process and the development of inflammatory processes in animal models.
\end{abstract}

Citation: Kolesnyk T. V. (2018) Anti-Inflammatory Therapy in the Prevention of Periodontal Diseases Tissue. Myths or Their Efficiency. World Science. 9(37). doi: 10.31435/rsglobal_ws/30092018/6136

Copyright: (C) 2018 Kolesnyk T. V. This is an open-access article distributed under the terms of the Creative Commons Attribution License (CC BY). The use, distribution or reproduction in other forums is permitted, provided the original author(s) or licensor are credited and that the original publication in this journal is cited, in accordance with accepted academic practice. No use, distribution or reproduction is permitted which does not comply with these terms.

In dentistry, using different drugs for bone metabolic processes normalization, prevention of periodontal tissue diseases normalization micro biocenosis oral $[1,2,3,4]$. But often without the use of selected drugs and diagnostics corresponding pathophysiological their selection is ineffective. Why? Clinicians are set in such a matter. Everyone decides its protocol, or clinical experience. But different clinical situations have their own characteristics and requires an individual approach.

Objective. The of this study was to investigate on phospholipase model for periodontitis in rats and viyasnit effectiveness of the proposed complex preventive periodontal tissue diseases.

Materials and methods. We have carried out experimental research complex preparations which have remineralizing, adaptogenic, antioxidant and anti-inflammatory properties: Capillary forte with bioflavonoids (adaptogenic, antiinflammatory, antioxidant) Vitaftor (remineralizing, antioxidant), elixir, "Grapefruit" (anti-inflammatory, reduces lipid peroxidation) rinser «Listerine-Zero» (antiinflammatory, anti-oxidant).

Female Wistar rats breeding herd months of age weighing 46-58 g were kept on phospholipase periodontitis model. The experiment used 30 rats, which were divided into groups of 10 pieces. as follows: 1- diet vivarium, 2 - phospholipase model periodontitis, 3 - phospholipase model and periodontitis complex preparations. Preparations "Capillary with bioflavonoids forte" and "Vitaftor" administered daily orally in the form of an aqueous slurry of $2.25 \mathrm{mg} /$ rat at the beginning of the experiment. Elixir "Grapefruit" was diluted 5 times daily and reflux was conducted in the oral cavity. Rinse «Listerine-Zero» as used 1 time per day. Rats were weighed every week, and performed recalculation doses. A month later, the animals were taken out of the experiment. Isolated jaw with teeth for calculating the degree of caries and alveolar bone atrophy, pulp, an upper jaw and gum tissue - for biochemical studies [5-9].

Results and discussion. Table. 1 summarizes the results of evaluation of the degree of damage tooth caries process and atrophy of the alveolar bone in animals. As can be seen from these data, under the influence of appliques on the gum $1 \%$ aqueous solution of phospholipase within 15 days of bone 
resorption of the alveolar bone of rats increased, what was judged by the significant increase in index atrophy ( $\mathrm{p}<0,001)$. Atrophy of the alveolar ridge on the model of periodontitis increased compared with the first group at $37.6 \%$. In animals of group 3 which received on the background applications phospholipase prophylactic complex, alveolar bone atrophy decreased as compared with the second group of 33.2\%, approaching the parameters in the control group "Diet vivarium".

Table 1. Atrophy of the alveolar ridge and intensity of lesions cariesin animals of experimental groups

\begin{tabular}{|c|c|c|c|c|}
\hline № & Groups & $\begin{array}{c}\text { atrophy, } \% \\
\text { alveolar } \\
\text { bone }\end{array}$ & $\begin{array}{c}\text { Number of } \\
\text { cavities 1 on average } \\
\text { a rat }\end{array}$ & $\begin{array}{c}\text { depth, } \\
\text { caries lesion } \\
\text { points }\end{array}$ \\
\hline 1 & Diet vivarium & $11,90,7 \pm$ & $\pm 5,004$ & $5,0 \pm 0,4$ \\
\hline 2 & periodontitis model & $19.5 \pm 0.8$ & $8,1 \pm 0,5$ & $9,1 \pm 0,8$ \\
phospholipase & $\mathrm{p}<0,001$ & $\mathrm{p}<0,001$ & $\mathrm{p}<0.001$ \\
\hline & phospholipase & $12.7 \pm 0.5$ & $<0,0015,7 \pm 0,4 \mathrm{p}>$ & $6,1 \pm 0,6$ \\
3 & $\begin{array}{c}\text { periodontitis models } \\
\text { and }\end{array}$ & $\mathrm{p}>0.1$ & 0,1 & $\mathrm{p}>0,1$ \\
& prophylactic & $\mathrm{p}_{1}$ & $1<0,005$ & $\mathrm{p}_{1},<0.001$ \\
& complex & & & \\
\hline
\end{tabular}

Note. $\mathrm{p}$ - an indicator of the reliability of differences from the figures in the group "vivarium Diet"; $\mathrm{p}_{1}$-confidence score differences from the indicators in the group phospholipase periodontitis models.

To determine the effect of phospholipase model model of periodontitis and preventive complex of the state of the gums animals its biochemical studies have been carried out. The results are shown in Table. 2.

Table 2. Enzyme activity in experimental groups of animals gingiva

\begin{tabular}{|c|c|c|c|c|c|}
\hline № & Groups & $\begin{array}{c}\text { Acid } \\
\text { phosphatase } \\
\text { activity, nkat / } \\
\mathrm{g} \text { of }\end{array}$ & $\begin{array}{c}\text { elastase } \\
\text { activity, nkat / } \\
\mathrm{g}\end{array}$ & $\begin{array}{c}\text { The content of } \\
\text { MDA, } \\
\text {.mu.mol / g of }\end{array}$ & $\begin{array}{c}\text { activity, } \\
\text { catalase } \\
\text { nkat / g }\end{array}$ \\
\hline 1 & diet vivarium & $2,7 \pm 0,3$ & $2011,6 \pm \pm$ & $9,30,8$ & $\pm 10,61,1$ \\
\hline 2 & $\begin{array}{c}\text { periodontitis model } \\
\text { phospholipase }\end{array}$ & $\begin{array}{c}6.3 \pm 0.6 \\
\mathrm{p}<0,001\end{array}$ & $\begin{array}{c}42,2 \pm 4,7 \\
\mathrm{p}<0,001\end{array}$ & $\begin{array}{c}20,5 \pm 2,3 \\
\mathrm{p}<0,001\end{array}$ & $\begin{array}{c}7,1 \pm 0,6 \\
\mathrm{p}<0.009\end{array}$ \\
\hline & $\begin{array}{c}\text { phospholipase } \\
\text { models of }\end{array}$ & $\begin{array}{c}4.08 \pm 0.30 \\
\mathrm{p}<0.004\end{array}$ & $\begin{array}{c}27,2 \pm 3,1 \\
\mathrm{p}<0.05\end{array}$ & $\begin{array}{c}12.1 \pm 1.5 \\
\mathrm{p}>0.1\end{array}$ & $\begin{array}{c}8,5 \pm 0,7 \\
\mathrm{p}>0.07 \\
\mathrm{p}_{1}>0.1\end{array}$ \\
& $\begin{array}{c}\text { periodontitis and } \\
\text { prophylactic } \\
\text { complex }\end{array}$ & $\begin{array}{c}\mathrm{p}_{1}<0,004 \\
\mathrm{p}_{1}<0.001\end{array}$ & $\begin{array}{c}\mathrm{p}_{1}<0,001 \\
\end{array}$ & &
\end{tabular}

Note. $\mathrm{p}$ - an indicator of the reliability of differences from the figures in the group vivarium diet;

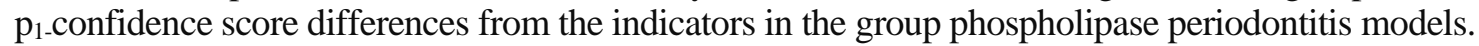

Evaluating the effectiveness of anti-inflammatory complex on markers of inflammation and elastase activity of acid phosphatase, we have noted an increase in these rates by more than 2 times in the group model phospholipase periodontitis compared with a group of Diet vivarium. In the same group of periodontitis phospholipase model and "prophylactic complex", these parameters are decreased in comparison with a group of phospholipase periodontitis model by $35.4 \%$.

Activity other proteolytic enzyme to bone - elastase - characterizes the degree of bone resorption. As shown in our experiment, phospholipase group of periodontitis models, the activity of this enzyme in the jaw bone tissue was significantly increased $\left(\mathrm{p}_{1}<0.001\right)$. Introduction prophylactic complex promoted inhibition of elastase activity by $42 \%\left(\mathrm{p}_{1}<0.001\right)$. The findings suggest that the ability of a set of preventive drugs significantly inhibit the enhanced resorption of bone tissue of the jaws.

Alkaline phosphatase activity (osteoblast marker) in the bone of the jaws of rats in the model group phospholipase periodontitis increased by $48.3 \%$ compared to the intact group $\left(\mathrm{p}_{1}<0.001\right)$. Appointment preventive complex stimulated the activity of osteoblasts, the marker, and therefore their physiological activity in the jaw bone tissue. Thus, this indicator increased by $71.3 \%$. It can be argued that the complex is effective in stimulating the functional activity of osteoblasts and mineralization processes in the bone tissue of the jaws when periodontitis model.

Conclusions. Phospholipase model periodontitis significantly aggravates bone resorption of the alveolar bone. Intensification of caries under the influence of a phospholipase of the solution, as 
shown by our study, is associated with impaired function mineralizing pulp. In addition, the gum in the modeling pathologies decreased antioxidant defenses against the backdrop of the intensification of LPO. The use of prophylactic complex effectively prevent violations in the pulp, gum, alveolar bone, prevented bone resorption of the alveolar process, the development of dental caries and inflammation in experimental animals. Analysis showed the jaw bone, that the simulation pathology also leads to an increase of acid phosphatase activity by $12.9 \%\left(\mathrm{p}_{1}<0.001\right)$, indicating that activation of bone resorption processes in the jaw tissue. Prophylaxis resulted in a significant inhibition of the flare activity of acid phosphatase, and thus resorption processes by $55.2 \%$. These indicators show parodont caries preventive effect and osteotrophic complex.

\section{REFERENCES}

1. Mazur I. P. Torn down bone metabolism in on the ailing generalizovany that periodontal Roads Ahead korektsii / I. P. Mazur // Journal practical likarya. - 2005. - № 6 - P. 14-22.

2. Pavlenko A. B. treatment and rehabilitation of patients with generalized periodontitis / A. B. Pavlenko, I. P. Mazur // Modern dentistry. Number 2. 2003. pp 33-37.

3. Zobnin V. V. Periodontal status and mineral component of the bone of the jaw after tooth extraction and prosthetic treatment bridges: dis. cand. honey. Sciences. / V.V. Zobnin. - Omsk, 1993 - 221 p.

4. Gromov V. O. The development of dysbiosis oral cavity for different types of dental prosthetics / V.O. Gromov, N. V. Rozhkov, O. E. Knava // News stomatologiï. - 2008. - № 1. - pp 11-12.

5. Biochemical markers of inflammation of oral tissue [guidelines] / A. P. Levitsky, Money O. V., Makarenko O. A. [and etc.]. - Odessa: KP "Odeska miska Drukarnya", 2010. - 15 p.

6. Jilin S. V. Modification of the method for determining the activity of catalase in biological substrates / S. V. Kirin // Lab. diagnostics. - 1999. - number 4. - P.45 - 46.

7. The enzymatic method of determination of dysbiosis oral cavity for screening pro- and prebiotics [method. R] / A. P. Levitsky, A. Makarenko, I. A. Selivanskaya [et al.]. - Kyiv, 2007. - 22 p.

8. Goryachkovsky A. M. Clinical biochemistry in the laboratory diagnosis [Supplemental Benefit] / A. M. Goryachkovsky [ed. 3rd vol. And added.] - Odes: Ekologiya, 2005. - P. 402 - 412.

9. Kolesnyk T. V. Efficiency of complex prophylaxis and treatment of inflammatory processes in somatically healthy young people / T. V. Kolesnyk, O. V. Denga / / Modern dentistry. - 2013. - No. 5 (69). - P. 44-48. 